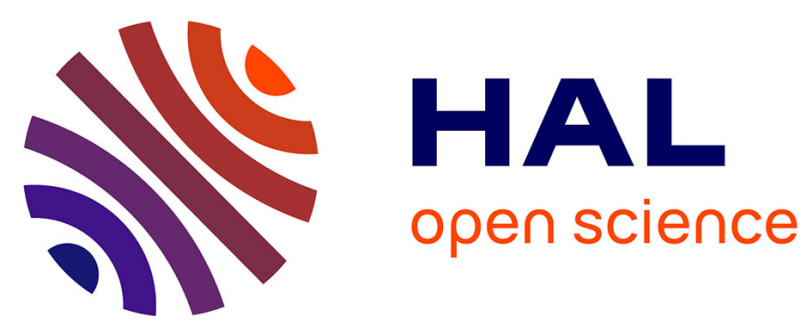

\title{
Modelling pasture production and soil temperature, water and carbon fluxes in Mediterranean grassland systems with the Pasture Simulation model
}

\author{
A. Pulina, R. Lai, L. Salis, G. Seddaiu, P. P. Roggero, Gianni Bellocchi
}

\section{- To cite this version:}

A. Pulina, R. Lai, L. Salis, G. Seddaiu, P. P. Roggero, et al.. Modelling pasture production and soil temperature, water and carbon fluxes in Mediterranean grassland systems with the Pasture Simulation model. Grass and Forage Science, 2017, 73 (2), 10.1111/gfs.12310 . hal-01637737

\section{HAL Id: hal-01637737 \\ https://hal.science/hal-01637737}

Submitted on 17 Nov 2017

HAL is a multi-disciplinary open access archive for the deposit and dissemination of scientific research documents, whether they are published or not. The documents may come from teaching and research institutions in France or abroad, or from public or private research centers.
L'archive ouverte pluridisciplinaire $\mathbf{H A L}$, est destinée au dépôt et à la diffusion de documents scientifiques de niveau recherche, publiés ou non, émanant des établissements d'enseignement et de recherche français ou étrangers, des laboratoires publics ou privés. 


\section{Modelling pasture production and soil temperature, water and carbon fluxes in Mediterranean grassland systems with the Pasture Simulation model}
A. Pulina ${ }^{1,2}$
R. Lai $^{1,2}$
L. Salis ${ }^{3}$
G. Seddaiu ${ }^{1,2}$
P. P. Roggero ${ }^{1,2}$
G. Bellocchi ${ }^{4}$

${ }^{1}$ Dipartimento di Agraria, University of Sassari, Sassari, Italy

${ }^{2}$ NRD - Desertification Research Centre, University of Sassari, Sassari, Italy

${ }^{3}$ AGRIS Sardegna - Servizio Ricerca per la Zootecnia, Sassari, Italy

${ }^{4}$ UREP, INRA, Clermont-Ferrand, France

\section{Correspondence}

A. Pulina, Dipartimento di Agraria, University of Sassari, Sassari, Italy.

Email: anpulina@uniss.it

\begin{abstract}
Grasslands play important roles in agricultural production and provide a range of ecosystem services. Modelling can be a valuable adjunct to experimental research in order to improve the knowledge and assess the impact of management practices in grassland systems. In this study, the PaSim model was assessed for its ability to simulate plant biomass production, soil temperature, water content, and total and heterotrophic soil respiration in Mediterranean grasslands. The study site was the extensively managed sheep grazing system at the Berchidda-Monti Observatory (Sardinia, Italy), from which two data sets were derived for model calibration and validation respectively. A new model parameterization was derived for Mediterranean conditions from a set of eco-physiological parameters. With the exception of heterotrophic respiration (Rh), for which modelling efficiency $(E F)$ values were negative, the model outputs were in agreement with observations (e.g., EF ranging from $\sim 0.2$ for total soil respiration to $\sim 0.7$ for soil temperature). These results support the effectiveness of PaSim to simulate $\mathrm{C}$ cycle components in Mediterranean grasslands. The study also highlights the need of further model development to provide better representation of the seasonal dynamics of Mediterranean annual species-rich grasslands and associated peculiar Rh features, for which the modelling is only implicitly being undertaken by the current PaSim release.
\end{abstract}

\section{KEYWORDS}

grassland production, mediterranean pastures, model calibration, PaSim, sheep grazing systems, soil respiration

\section{1 | INTRODUCTION}

Grasslands and rangelands play a crucial role on supporting livestock systems and provide a wide variety of ecosystem services (EIP-AGRI, 2016). They cover about $50 \%$ of European Mediterranean areas, which represent the largest region in the world characterized by a Mediterranean-type climate (Cosentino et al., 2014). In the Mediterranean region, as well as in other parts of the world with similar climate, the grassland vegetation is dominated by $\mathrm{C}_{3}$ annual plant species characterized by a variety of traits that ensure their persistence through self-reseeding under varying rainfall and temperature patterns (Bagella et al., 2013; Porqueddu et al., 2016; Roggero \& Porqueddu, 1999). Mediterranean grasslands are almost exclusively secondary prairies, shaped by a range of anthropogenic practices, often belonging to mixed agro-ecosystems characterized by the presence of shrubs and trees (Bagella, Caria, Farris, Rossetti, \& Filigheddu, 2016). The Mediterranean grassland growing-season starts in autumn, with plant germination, and ends in late spring, followed by summer senescence. During this period, which ranges from 180 to 270 days depending on weather and altitude, typically two maximum growth rates are observed: the first one occurring in mid-autumn and the second in April (Cavallero et al., 1992). Annual production is 
strongly constrained by summer drought duration and, even to a greater extent, by the variability of autumn and spring precipitation regimes (Gea-Izquierdo, Montero, \& Cañellas, 2009; Golodets et al., 2015).

Grasslands have a crucial role in the global C cycle because of their contribution to $\mathrm{C}$ sequestration in the biosphere (Ciais et al., 2010; Lal, 2004). The soil respiration (SR) is a core component of the total C cycle. Under Mediterranean climatic conditions, it is possible to observe wide SR temporal variations due to the dynamics of both soil temperature (Soil T) and soil water content (SWC) (Rey et al., 2002). Consistently, from winter to early spring, soil T was observed to act as the main driver of SR, while during summer SWC mostly controls this process (Almagro, López, Querejeta, \& MartínezMena, 2009; de Dato, De Angelis, Sirca, \& Beier, 2010; Lai, Lagomarsino, Ledda, \& Roggero, 2014; Oyonarte, Rey, Raimundo, Miralles, \& Escribano, 2012). Although in humid periods SR variability can be explained by an exponential relationship between Soil $\mathrm{T}$ and SR (Davidson, Belk, \& Boone, 1998), under drought conditions SWC turns into the most important factor affecting SR dynamics (Almagro et al., 2009; Correia et al., 2012; Oyonarte et al., 2012). During the summer period, SR is constrained by water-limited microbial activity (Davidson \& Janssens, 2006). Because of long dry periods occurring in Mediterranean environments, water deficit is considered in this region as the main limiting factor of the interannual variation of terrestrial $C$ ecosystem exchanges, as it causes large reductions in primary productivity and affects SR (Reichstein et al., 2002). Moreover, in Mediterranean agro-silvo-pastoral systems not only abiotic factors could affect SR dynamics, but also soil management and land use (Costa, Freitas, \& Sousa, 2013).

The Pasture Simulation model (PaSim, https://www1.clermont. inra.fr/urep/modeles/pasim.htm, accessed on 1 January 2017), originally developed by Riedo, Grub, Rosset, and Fuhrer (1998), deals with grassland vegetation and major soil processes (water, $\mathrm{C}$ and $\mathrm{N}$ cycling) on a plot-scale configuration and performs analysis of management options, through the control of fertilizer application, irrigation, cutting and grazing. The model was used to simulate temperate grasslands in France to assess climate change impacts (Graux, Bellocchi, Lardy, \& Soussana, 2013; Lardy, Bachelet, Bellocchi, \& Hill, 2014; Vital et al., 2013) and the global warming potential of foragebased livestock systems (A.-I. Graux, Lardy, Bellocchi, \& Soussana, 2012; A. I. Graux et al., 2011). A generic parameterization of the model was established for regional-scale analyses of $\mathrm{C}$ and water cycles in Europe (Ma et al., 2015), where it generally performs comparatively better than the competing models (e.g., Sándor et al., 2016). These studies contributed to the recognition of PaSim as a suitable tool to reproduce biophysical and biogeochemical processes of managed grasslands. A detailed application of the model for Mediterranean grasslands has not previously been undertaken.

The aim of this study was to evaluate whether PaSim could be reasonably used to estimate $C$ fluxes (i.e., biomass and soil respiration) and soil biophysical components (i.e., water and temperature) in a Mediterranean grassland system. Considering the characteristics of these agro-ecosystems, the objective of the study was to provide a framework for the quantitative assessment of the processes driving $\mathrm{C}$ cycle and water balances, as influenced by management practices.

\section{MATERIALS AND METHODS}

\section{1 | Study site}

The study site is located in the Long Term Observatory of Berchidda-Monti (NE Sardinia, Italy) $\left(40^{\circ} 49^{\prime} \mathrm{N}\right.$, 9 $9^{\circ} 17^{\prime}-9^{\circ} 19^{\prime} \mathrm{E} ; 287$ $325 \mathrm{~m}$ a.s.l.). The site is representative of Sardinian grassland-based dairy sheep farming systems and shares several commonalities with the agro-silvo-pastoral systems widespread in the Mediterranean basin, in particular in the Iberian Peninsula (Caballero et al., 2009). In Sardinia, permanent grasslands are the most common form of land use, occupying over 700,000 ha, i.e., $~ 30 \%$ of total area of the island (Ravenna, 2013). In the study site, the mean annual rainfall is $632 \mathrm{~mm}$, of which 70\% occurs during October to May. The mean annual temperature is $14.2^{\circ} \mathrm{C}$, and the aridity index (mean annual precipitation divided by mean annual reference evapotranspiration) is 0.53. According to the classification of USDA (2010), the dominant soil type is a Typic Dystroxerept, with sandy loam texture in the first soil horizon, derived from a granitic substratum (Carmignani et al., 2012).

\subsection{The Pasture Simulation model}

PaSim (Riedo et al., 1998) simulates water, $\mathrm{C}$ and $\mathrm{N}$ cycling in grassland systems in a subdaily (1/50 of a day) time step. Microclimate, soil biology and physics, vegetation, grazing herbivores and management practices are interacting modules. Simulations are not spatially resolved (e.g., patchiness is not considered) because each simulated plot is assumed to be homogeneous and input/output data are assumed to be representative of the entire field. Photosyntheticassimilated $C$ is either allocated dynamically to one root and three shoot compartments (each consisting of four age classes) or lost through animal metabolism (ecosystem respiration). Accumulated aboveground biomass is either cut or grazed, or enters a litter pool. Management includes organic and mineral $\mathrm{N}$ fertilizer application, mowing and grazing, with parameters set by the user or optimized by the model. Additional details about model processes are provided in the supplementary material.

\section{3 | Model input data}

Two grassland fields (Table 1) within two private farms in the Berchidda-Monti Observatory were identified (BM1 and BM2, having an area of 3.094 and 2.187 ha respectively), for which suitable data sets were available to set up distinct model input files and parameterize the model.

The meteorological data set was compiled for the period 20082014 from two weather stations located at the study site, owned by the Regional Environmental Protection Agency of Sardinia-Meteoclimatic Department (http://www.sar.sardegna.it). The soil profile 


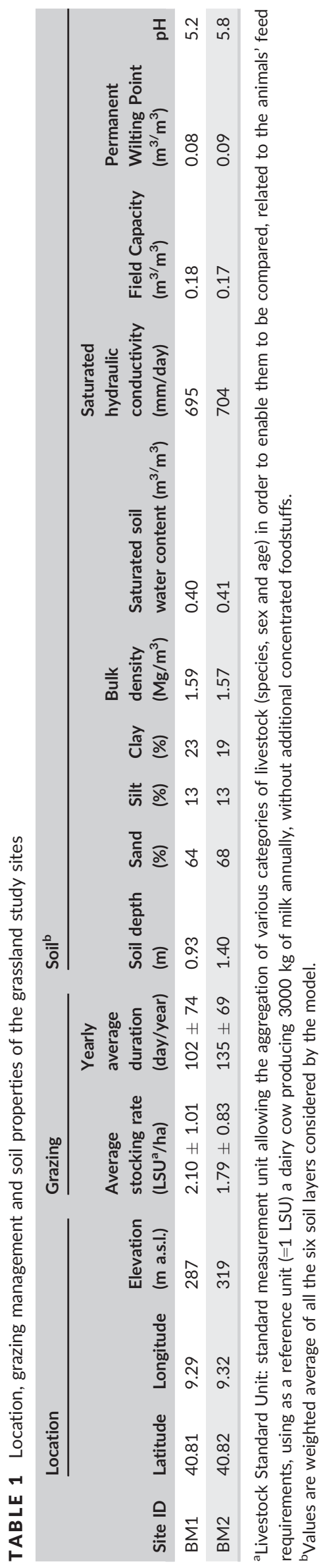

was sampled according to horizons and depth, and analysed for particle-size distribution, bulk density and $\mathrm{pH}$. Soil sampling and analyses methods were described by Seddaiu et al. (2013). Soil hydraulic properties (saturated soil water content, saturated hydraulic conductivity, field capacity and permanent wilting point) were estimated from the measured soil texture and soil organic matter according to Saxton and Rawls (2006). The grassland management was monitored at field scale during the observational periods through systematic interviews with farmers. In this way, it was possible to build a data set of daily animal stocking rate. Daily animal stocking rates were mimicked by model management requirements approximated at 10 grazing events per year, by aggregating the days close to each other when grazing occurred for only a few hours per day and calculating in these periods the weighted stocking rates.

\section{4 | Model parameterization and evaluation}

Field data resources were segregated into two groups: a sample (BM1) was used to estimate model parameters (calibration set); an independent sample (BM2) was used to validate model results (validation set).

The biophysical and biogeochemical data of the grassland systems in BM1 and BM2 were mainly represented by measurements of soil temperature at $-0.10 \mathrm{~m}$ (soil $\mathrm{T},{ }^{\circ} \mathrm{C}$ ), soil water content at $0.03 \mathrm{~m}\left(\mathrm{SWC}, \mathrm{m}^{3} / \mathrm{m}^{3}\right)$, and total and heterotrophic soil respiration (SR and Rh, respectively, $\mathrm{kg} \mathrm{C}-\mathrm{CO}_{2} \mathrm{~m}^{2} /$ day). In addition, data on grassland dry-matter (DM) production $\left(\mathrm{kg} \mathrm{DM} \mathrm{m}^{-2}\right.$ day $^{-1}$ ) from both grazed and ungrazed plots (GRDM and NGDM, respectively) were available. The model was calibrated based on a set of influential parameters (Table 2) identified in previous studies (Ben Touhami, Lardy, Barra, \& Bellocchi, 2013; Ma et al., 2015).

Pasture production was measured from February 2009 to May 2010, and from February 2013 to May 2014 at monthly intervals by cutting the herbage sward inside and outside randomly positioned fences $(10 \mathrm{~m} \times 10 \mathrm{~m})$, so as to quantify herbage biomass without grazing (NGDM) and the grazed herbage on offer (GRDM) respectively. To determine biomass DM, samples $(n=3)$ were taken on $0.5 \mathrm{~m}^{2}$ areas, immediately stored in plastic bags kept cool, and then brought to the laboratory within $4 \mathrm{hr}$ to be dried in a ventilated oven at $65^{\circ} \mathrm{C}$ until achieving constant weight.

Hourly measurements of soil $\mathrm{T}$ and SWC were taken with a WatchDog 1000 Series Micro Station (Spectrum Technologies, Inc., IL, USA, http://www.specmeters.com), equipped with a WaterScout SM 100 Soil Moisture Sensor and Soil Temperature Sensor for soil T and SWC respectively.

A portable, closed-chamber, soil respiration system (EGM-4 with SRC-1, PP-Systems, Hitchin, UK, http://ppsystems.com) was used to measure in situ SR and Rh, between 8:30 and 13:00 (solar time) in order to collect data representative of daily means (Almagro et al., 2009 and citations therein). The measurements were carried out from 1 August 2013 to 5 August 2014 at weekly to monthly intervals $(n=2)$, depending on grassland growth phases and weather conditions (Rey et al., 2002). Measurements of Rh were made in 
TABLE 2 Summary of the PaSim parameters considered for calibration. For each parameter, two sets of values are reported: reference values or ranges of values from previous studies (Ben Touhami et al., 2013; Ma et al., 2015) and values obtained from the calibration performed in this study

\begin{tabular}{|c|c|c|c|c|c|}
\hline \multirow[b]{3}{*}{ Parameter } & \multirow[b]{3}{*}{ Description } & \multirow[b]{3}{*}{ Unit } & \multicolumn{3}{|l|}{ Values } \\
\hline & & & \multicolumn{2}{|l|}{ Proposed } & \multirow[b]{2}{*}{ Calibration } \\
\hline & & & Min & Max & \\
\hline Canopy Height Parameter 1 & $\begin{array}{l}\text { This parameter expresses the leaf area } \\
\text { index for which canopy is half the } \\
\text { maximum height }\end{array}$ & $\mathrm{m}^{2} / \mathrm{m}^{2}$ & 4.0 & & 2.0 \\
\hline The root turnover parameter & The root turnover rate at $20^{\circ} \mathrm{C}$ & $d^{-1}$ & 0.0096 & 0.0144 & 0.0144 \\
\hline The shoot turnover parameter & The shoot turnover rate at $20^{\circ} \mathrm{C}$ & $d^{-1}$ & 0.0360 & 0.0540 & 0.0250 \\
\hline $\begin{array}{l}\text { Light-saturated leaf photosynthetic } \\
\text { rate for reproductive stage }\end{array}$ & $\begin{array}{l}\text { They represent the influence of } \\
\text { developmental stage on the light-saturated }\end{array}$ & 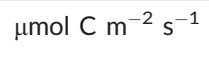 & 15.0 & 22.5 & 14.0 \\
\hline $\begin{array}{l}\text { Light-saturated leaf photosynthetic } \\
\text { rate for vegetative stage }\end{array}$ & $\begin{array}{l}\text { leaf photosynthetic rate (defined as standard } \\
\text { conditions of temperature, atmospheric } \mathrm{CO}_{2} \\
\text { concentration), which is a component of the } \\
\text { rate of canopy photosynthesis. }\end{array}$ & & 10.0 & 15.0 & 10.0 \\
\hline $\begin{array}{l}\text { Temperature dependence } \\
\text { factor of the soil respiration }\end{array}$ & $\begin{array}{l}\text { It multiplies the temperature-dependent } \\
\text { function to estimate soil respiration }\end{array}$ & - & 0.7 & 2.0 & 0.7 \\
\hline
\end{tabular}

${ }^{a}$ The obtained parameter is an average value of measurements performed at the same time of DM samplings.

${ }^{\mathrm{b}}$ The obtained root distribution is an assumption made according to model soil layers, which are specified in supplementary material.

trenched plots (Hanson, Edwards, Garten, \& Andrews, 2000), in which soil was isolated with a PVC cylinder $(0.40 \mathrm{~m}$ diameter and $0.25 \mathrm{~m}$ height) open at both ends (Lai, Seddaiu, Gennaro, \& Roggero, 2012) and inserted into the soil profile till $0.20 \mathrm{~m}$ depth according to Unger et al. (2009).

For the calibration purpose, 10 model parameters were modified within their plausible ranges (Table 2) through a trial-and-error process comparing the model predictions with observational data to ensure realistic representation of a variety of outputs. They govern (i) canopy morphology and phenological features, in particular maximum specific leaf area, thermal sum for the transition from reproductive to vegetative phase, parameters describing the canopy height development and root-shoot turnover rates, and a parameter of root distribution in different soil layers, (ii) canopy physiological features, in particular parameters describing $\mathrm{CO}_{2}$ absorption rates at both vegetative and reproductive stages; and (iii) soil biological activity, in particular a parameter governing soil respiration.

The agreement of model outputs with observational data of soil T, SWC, SR, Rh, GRDM and NGDM was assessed through a set of indices and by graphical reports applied to both calibration and validation sets. The multiplicity of aspects to be accounted for a multiperspective assessment of model performance requires the use of a variety of metrics for model evaluation (Bellocchi, Rivington, Donatelli, \& Matthews, 2010). These metrics (Table 3) include the goodness-of-fit $R^{2}$ (coefficient of determination) which assesses the linear dependence between modelled and observed data and the proportion of the total variation explained by the model, and a set of metrics such as the mean differences (BIAS), the per cent relative root mean square error (RRMSE), the coefficient of residual mass (CRM), the modelling efficiency (EF) and the index of agreement (d) which assess quantitative differences.

To test the robustness of the obtained PaSim parameterization, model performance was assessed also for a set of ancillary observed data. The parameterization was tested on (i) grassland DM production under $\mathrm{N}$ fertilizer conditions, (ii) the herbage $\mathrm{DM}$ intake from pasture of grazing animals, (iii) the $\mathrm{C}$ and $\mathrm{N}$ input from grazing animals. These ancillary data were collected in both BM1 and BM2, and overall metrics were calculated on both sites. The ancillary 
TABLE 3 Index of model performance used in model assessment

\begin{tabular}{|c|c|c|c|c|}
\hline Performance metric & Equation & Unit & Value range and purpose & References \\
\hline $\begin{array}{l}\text { BIAS, mean difference of } \\
\text { simulations and observations }\end{array}$ & $\mathrm{BIAS}=\frac{\sum_{\mathrm{i}=1}^{n}\left(P_{\mathrm{i}}-\mathrm{O}_{\mathrm{i}}\right)}{\mathrm{n}}$ & $\begin{array}{l}\text { Unit of the } \\
\text { variable }\end{array}$ & $\begin{array}{l}-\infty<\text { BIAS }<+\infty \\
\text { The best values are close to } 0 . \\
\text { Negative values: underestimation; } \\
\text { positive values: overestimation }\end{array}$ & $\begin{array}{l}\text { (Addiscott \& Whitmore, } \\
\text { 1987) }\end{array}$ \\
\hline $\begin{array}{l}\text { RRMSE, relative root } \\
\text { mean square error }\end{array}$ & RRMSE $=\frac{\sqrt{\frac{\sum_{i=1}^{n}\left(p_{i}-o_{i}\right)^{2}}{n}}}{\overline{0}} \times 100$ & - & $\begin{array}{l}0 \leq \text { RRMSE } \leq+\infty \\
\text { The best values are close to } 0\end{array}$ & (Fox, 1981) \\
\hline$E F$, modelling efficiency & $E F=\frac{\sum_{i=1}^{n}\left(O_{i}-\bar{O}\right)^{2}-\sum_{i=1}^{n}\left(P_{i}-O_{i}\right)^{2}}{\sum_{i=1}^{n}\left(O_{i}-\bar{O}\right)^{2}}$ & - & $\begin{array}{l}-\infty<\mathrm{EF} \leq+1 \\
\text { The best values are close to } 1\end{array}$ & $\begin{array}{l}\text { (Greenwood, Neeteson, \& } \\
\text { Draycott, 1985) }\end{array}$ \\
\hline d, Index of Agreement & $\mathrm{d}=1-\frac{\sum_{\mathrm{i}=1}^{\mathrm{n}}\left(\mathrm{P}_{\mathrm{i}}-\mathrm{O}_{\mathrm{i}}\right)^{2}}{\sum_{\mathrm{i}=1}^{\mathrm{n}}\left(\left|\mathrm{P}_{\mathrm{i}}-\overline{\mathrm{O}}\right|+\left|\mathrm{O}_{\mathrm{i}}-\overline{\mathrm{O}}\right|\right)^{2}}$ & - & $\begin{array}{l}0<\mathrm{d}<1 \\
\text { The best values are close to } 1\end{array}$ & (Willmott \& Wicks, 1980) \\
\hline
\end{tabular}

$\mathrm{P}$, predicted value; $\mathrm{O}$, observed value; $n$, number of $\mathrm{P} / \mathrm{O}$ pairs; $i$, each of $\mathrm{P} / \mathrm{O}$ pairs; $\overline{\mathrm{O}}$, mean of observed values; $\overline{\mathrm{P}}$, mean of predicted values.

observations methods, results and relative metrics values are reported as supplementary material.

The RStudio extension of R-language computing environment (version 3.1.1) (RCoreTeam, 2014) was used to perform linear regression analysis between observed and simulated data for each output. The regression significance was tested using the ANOVA function of the software base package. Residuals analysis was performed by combining both BM1 and BM2 data sets for each output. Standardized residuals were obtained by dividing differences between simulations and observations by standard deviation.

\section{RESULTS}

At both study sites, observed GRDM and NGDM (Figure 1) showed the highest values in spring, for which the interannual means were $3.67 \pm 0.54$ and $4.37 \pm 0.64 \mathrm{Mg} \mathrm{DM} \mathrm{ha}^{-1}$ in $\mathrm{BM} 1$, and $2.69 \pm 0.35$ and $4.29 \pm 0.57 \mathrm{Mg} \mathrm{DM}$ ha $^{-1}$ in BM2 for GRDM and NGDM respectively. There was no DM production during summer. The average observed and simulated DM growth rates in NGDM are shown in Figure 2.

Soil $\mathrm{T}$ dynamics in BM1 ranged from $8.9^{\circ} \mathrm{C}$ in February to $25.7^{\circ} \mathrm{C}$ in August, and in $\mathrm{BM} 2$ from $8.3^{\circ} \mathrm{C}$ in December to $26.7^{\circ} \mathrm{C}$ in August. Annual mean values were 17.5 and $17.8^{\circ} \mathrm{C}$, respectively, in BM1 and BM2 (Figure 3). Compared to Soil T, SWC showed the opposite dynamics in both BM1 and BM2 data sets. Maximum values were observed in autumn-winter, when SWC reached $0.32 \mathrm{~m}^{3} /$ $\mathrm{m}^{3}$ at both sites, while minimum SWC values were observed in summer: $0.08 \mathrm{~m}^{3} / \mathrm{m}^{3}$ in $\mathrm{BM} 1$ and $0.05 \mathrm{~m}^{3} / \mathrm{m}^{3}$ in $\mathrm{BM} 2$.

At both BM1 and BM2, the SR and Rh (Figure 4) showed a two-peak profile. Maximum $\mathrm{SR}$ values were as follows: $3.31 \pm 0.49 \mathrm{~g} \mathrm{C}^{-} \mathrm{CO}_{2} / \mathrm{m}^{2} /$ day observed on 11 September 2013 and
$6.45 \pm 0.43 \mathrm{~g} \mathrm{C}-\mathrm{CO}_{2} / \mathrm{m}^{2} /$ day on 23 April 2014 at $\mathrm{BM} 1$, and $2.62 \pm 1.38 \mathrm{~g} \mathrm{C}-\mathrm{CO}_{2} / \mathrm{m}^{2} /$ day on 11 September 2013 and

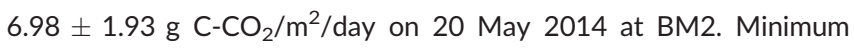
SR values were observed on 27 September 2013, when fluxes were $1.18 \pm 0.20 \mathrm{~g} \mathrm{C}-\mathrm{CO}_{2} / \mathrm{m}^{2} /$ day at BM1 and $1.05 \pm 0.20 \mathrm{~g} \mathrm{C}-\mathrm{CO}_{2} /$ $\mathrm{m}^{2} /$ day at BM2. Maximum Rh values were as follows: $2.49 \pm 0.52 \mathrm{~g}$ $\mathrm{C}-\mathrm{CO}_{2} / \mathrm{m}^{2} /$ day on 8 November 2013 and $3.31 \pm 0.43 \mathrm{~g} \mathrm{C}-\mathrm{CO}_{2} / \mathrm{m}^{2} /$

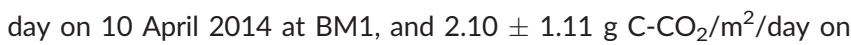
8 November 2013 and $3.37 \pm 0.29 \mathrm{~g} \mathrm{C}^{-} \mathrm{CO}_{2} / \mathrm{m}^{2} /$ day on 23 April 2014 at BM2. Minimum Rh fluxes were observed on 27 September 2013, when $\mathrm{CO}_{2}$ fluxes were $0.56 \pm 0.23 \mathrm{~g} \mathrm{C}-\mathrm{CO}_{2} / \mathrm{m}^{2} /$ day at $\mathrm{BM} 1$ and $0.85 \pm 0.00 \mathrm{~g} \mathrm{C}-\mathrm{CO}_{2} / \mathrm{m}^{2} /$ day at $\mathrm{BM} 2$.

Deviations from published ranges or values were observed for four calibrated parameters (Table 2). The obtained leaf area index when canopy is half the maximum height $\left(2.0 \mathrm{~m}^{2} / \mathrm{m}^{2}\right)$ was set lower than the default value $\left(4.0 \mathrm{~m}^{2} / \mathrm{m}^{2}\right)$. The shoot turnover parameter $\left(0.0250 \mathrm{~d}^{-1}\right)$ and the light-saturated leaf photosynthetic rate for reproductive stage $\left(14.0 \mu \mathrm{mol} \mathrm{C} \mathrm{m} \mathrm{C} \mathrm{s}^{-1}\right)$ were also lower than minimum values from previous studies $\left(0.0360 \mathrm{~d}^{-1}\right.$ and $15.0 \mu \mathrm{mol} \mathrm{C} \mathrm{m}{ }^{-2} \mathrm{~s}^{-1}$ respectively). The parameters of relative root distribution in each soil layers were also different from the original values.

The calibrated model substantially matched the observed data, with the exception of Rh (Table 4). Overall, the best performance was observed for soil T and SWC simulations, with EF ranging from 0.4 0.7. Best metrics were generally obtained with the calibration data set, with a few exceptions such as the RRMSE values calculated for NGDM and GRDM, which were better with the validation set. The performance was not satisfactory when the model was used to simulate Rh, as shown by the negative EF values with both calibration and validation data sets. Relationships between observed and simulated data in both BM1 and BM2 for Soil T, SWC, GRDM, 


\section{BM1}
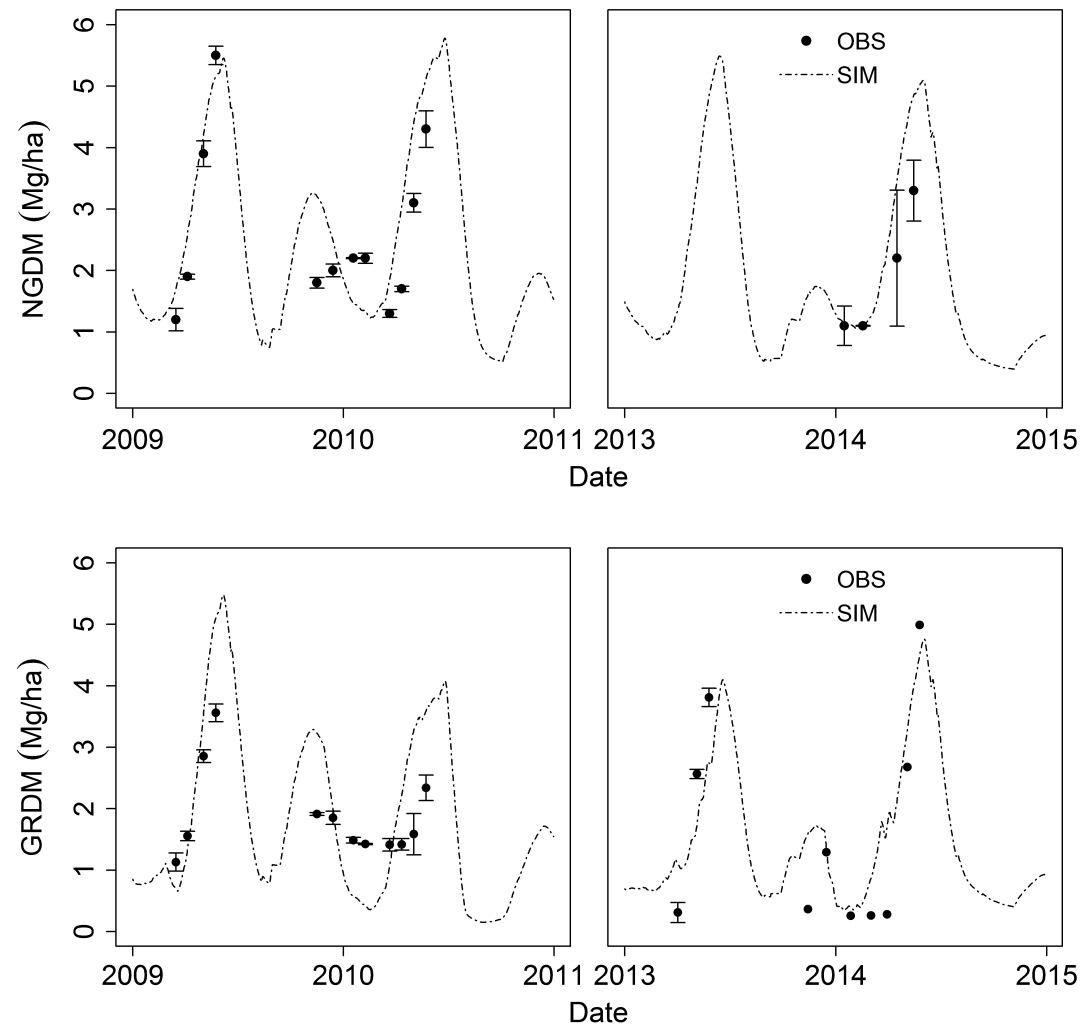

BM2
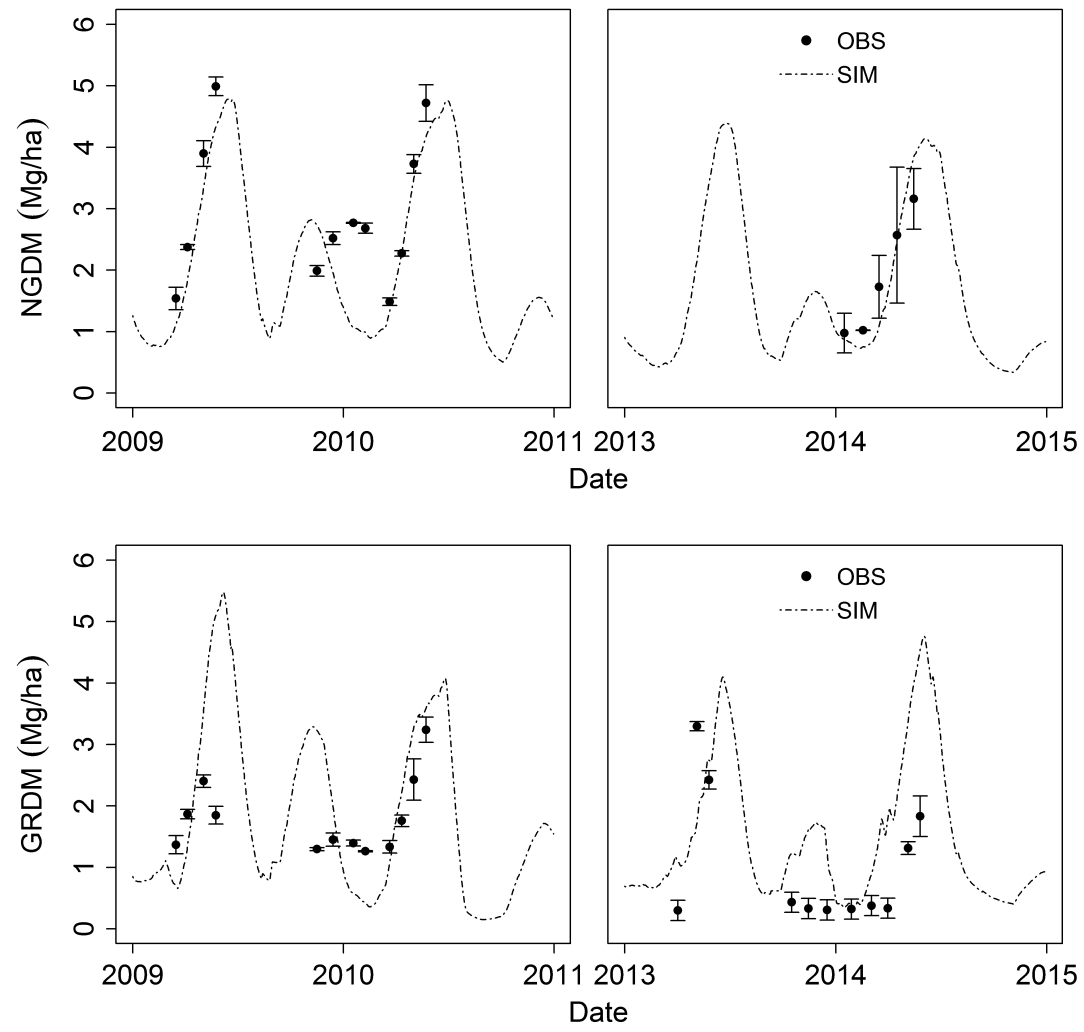
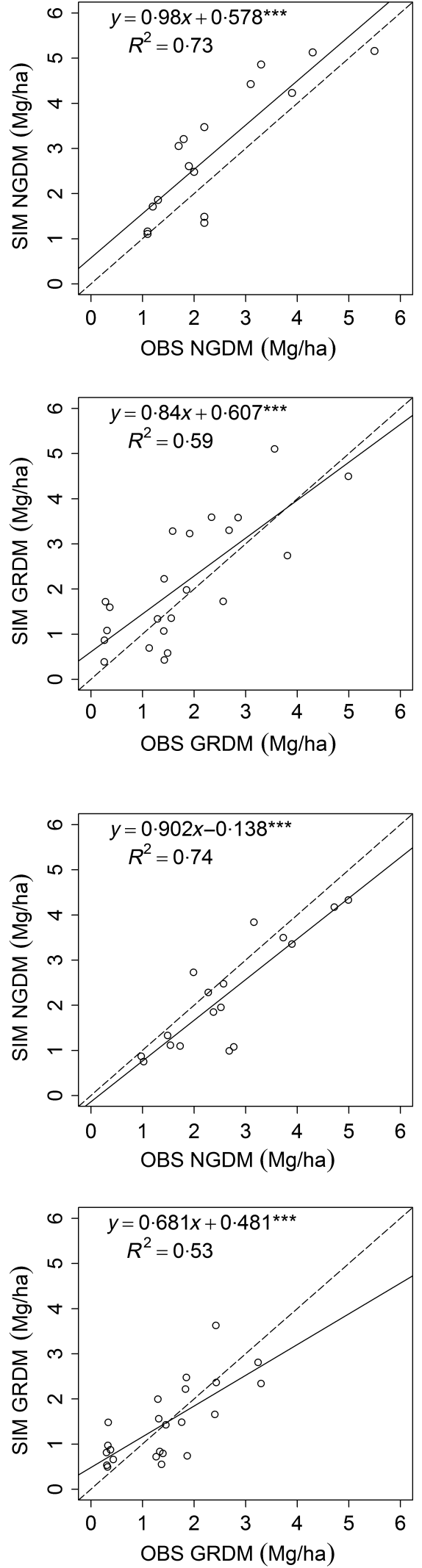

FIGURE 1 Calibration (BM1) and validation (BM2) results for GRDM (DM biomass in grazed plots, Mg DM ha ${ }^{-1}$ ) and NGDM (DM biomass in ungrazed plots, $\mathrm{Mg} \mathrm{DM} \mathrm{ha}{ }^{-1}$ ) and relation between observed (OBS) and simulated (SIM) data. Bars indicate the observed data standard error $(n=2) .(* * * p<.001)$ 


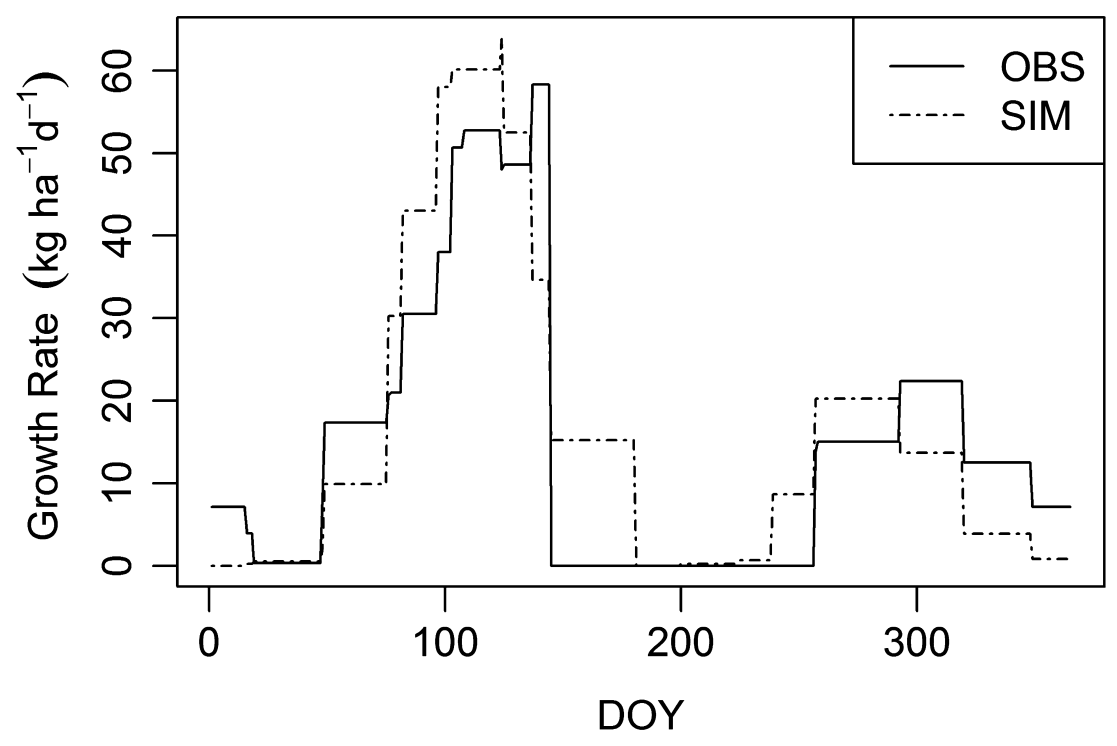

FIGURE 2 Observed and simulated average values of DM growth rate in NGDM. DOY, day of year; OBS, observed data; SIM, simulated data

NGDM and SR were always significant at $p<.001$ with high $\mathrm{R}^{2}$ values, in particular for the calibration phase (Figures 1, 3 and 4; Table 4). Less significant relationships were found between observed and simulated Rh (Figure 4; Table 4). An analysis of the standardized residuals (Figure 5) showed seasonal patterns, which differed depending on the output. In particular, deviations from the $95 \%$ confidence limits highlight underestimation of soil $\mathrm{T}$ towards the end of the year and overestimation of SWC roughly uniformly over the year. Values outside $95 \%$ limits were observed in late spring (from day of year 80 to 171) and summer period (from day of year 171 to 265) for SR and Rh outputs.

\section{DISCUSSION}

For NGDM, performance metrics showed satisfactory results with both calibration and validation data sets. RRMSE values in the range 28-37\% are comparable to those reported for multilocation simulations in France with PaSim (A. I. Graux et al., 2011). The simulation of GRDM (with RRMSE around 50\%) was also satisfactory, considering that this output is affected by higher uncertainties than NGDM. In this study, PaSim showed an overall satisfactory capability to simulate dairy sheep post-grazing effects on grassland growth and after-grazing regrowth. This was obtained despite the time-based approximation required to set the PaSim management input file, which only allows for ten grazing events per year to be prescribed; that does not reflect the business-as-usual grazing regimes of dairy sheep semi-extensive farming systems in Mediterranean regions. In fact, these systems are different to continental cattle grazing systems which usually characterized by larger pasture areas for livestock management, and they are often carried out in small areas, where animals graze over a few hours per day with different grazing regimes related to forage availability, phenological plant stages, sheep physiology, nutritional needs and farm typology (Molle, Decandia, Cabiddu, Landau, \& Cannas, 2008). Despite the satisfactory overall simulation of the cumulated biomass, limitations in the simulation of the grassland production dynamics were observed in the autumn season. In autumn, the simulated grass growth started about 25 days earlier than was observed in the field. Moreover, the simulated maximum grassland growth rate occurred 20 days earlier than the field observations. This difference between simulated and observed data was attributed to the limitations of PaSim in simulating the mechanistic process underlying plant growth, which is meant to reflect the dynamics of perennial plant species. In fact, when optimal conditions of soil T and SWC occur after the season break summer, the model simulates plant growth as if the sward was composed of well-established perennial species. Under Mediterranean conditions, autumn grassland regrowth is related to the germination of new seedlings of annual species, and hence, plant growth rates are slower than expected for perennials for the same soil $\mathrm{T}$ and SWC conditions.

Overall, the evaluation metrics obtained for soil T and SWC simulations were comparable to those obtained in a previous study undertaken using PaSim across a range of European grasslands ( $\mathrm{Ma}$ et al., 2015). In autumn, soil T was underestimated, as highlighted by residuals analysis. This was consistent with a greater simulated than observed aboveground biomass, as a lower soil cover would have resulted into less shading and hence higher daily mean soil $\mathrm{T}$ due to the effect of vegetation cover on soil temperature. The marked fluctuations of the simulated SWC can be attributed to the high variability inherent to the water balance in the topsoil (Li et al., 2015), where most influential biological and biophysical processes occur showing greater temporal and spatial variability (Cambardella et al., 1994).

The model performance indices for SR were acceptable, considering the high spatial variation inherent to this variable (Oyonarte et al., 2012), as was also observed previously in the BerchiddaMonti Observatory (Lai, 2011). The spatial variability of soil C fluxes affects the model's ability to simulate SR and Rh dynamics (Mekonnen, Grant, \& Schwalm, 2016). The seasonal fluctuations and 
BM1
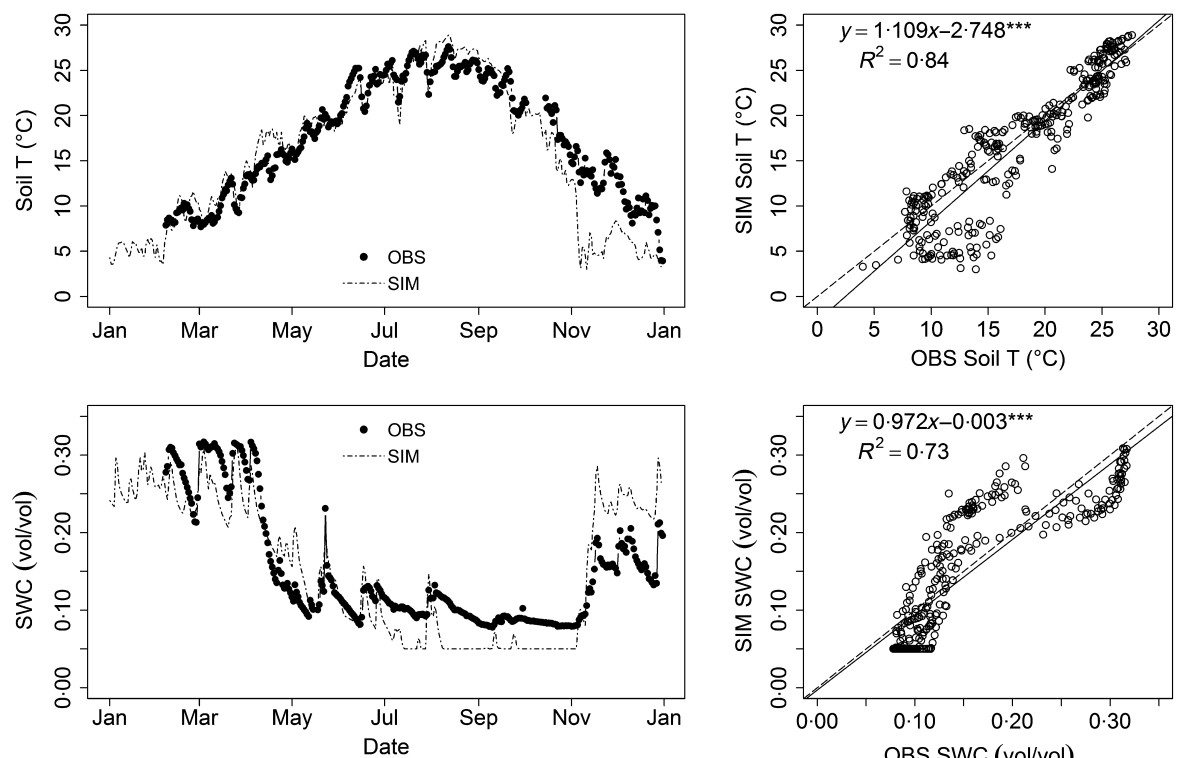

BM2
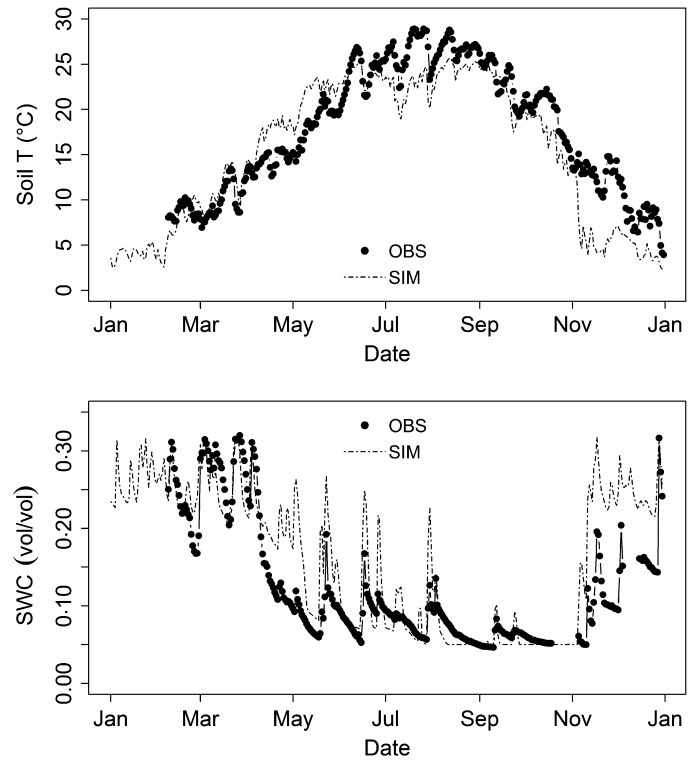
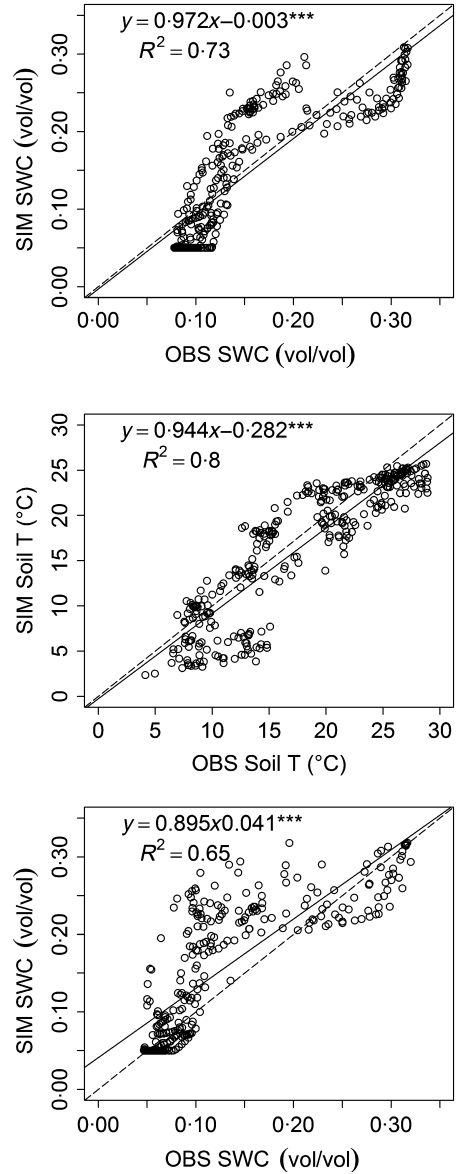

FIGURE 3 Calibration (BM1) and validation (BM2) results for Soil T (soil temperature, ${ }^{\circ} \mathrm{C}$ ) and SWC at $0.03 \mathrm{~m}$ (soil water content, $\mathrm{m}^{3 /} \mathrm{m}^{3}$ ) and relation between observed (OBS) and simulated (SIM) data. $(* * * p<.001)$ amount of total SR were satisfactorily represented by the model. The RRMSE values were similar to those obtained by Correia et al. (2012), who compared alternative statistical models in a multisite analysis in the Mediterranean basin. For SR, the values of $\mathrm{R}^{2}$ and $\mathrm{EF}$ found in this study were similar to those reported in the meta-analysis performed by Chen et al. (2010) on yearly simulated values for a broad variety of climate areas and land uses including Mediterranean grassland areas. Under Mediterranean conditions, the effects of soil $\mathrm{T}$ on both $\mathrm{SR}$ and $\mathrm{Rh}$ can be flattened by the inhibitory effect of low SWC on $\mathrm{C}-\mathrm{CO}_{2}$ fluxes from soil, when SWC limits microbial activity (Davidson et al., 1998; Rey et al., 2002). When comparing observed and simulated data at both BM1 and BM2, it emerged that the ability of PaSim to simulate soil respiration strongly depends on soil T. The effect of SWC becomes apparent when examining the autotrophic component of SR: in fact, the simulated SR during the summer drought period is almost completely due to $\mathrm{Rh}$. This demonstrates the ability of PaSim to simulate satisfactorily the droughtstress effects on plant growth, although the modelled mechanisms of senescence do not entirely reflect the peculiarities of Mediterranean grasslands. The analysis of residuals highlighted a considerable underestimation of soil $T$ dynamics and an overestimation of SWC in autumn. Despite this, SR and Rh residuals in autumn were within the $95 \%$ confidence intervals. The role of soil $\mathrm{T}$ in determining underestimation of the annual soil $\mathrm{C}-\mathrm{CO}_{2}$ effluxes was not substantial. The negative EF values observed in the validation phase for $\mathrm{Rh}$ also could be due to differences between within-model conceptualization of $\mathrm{Rh}$ and what it is actually measured in the field. In fact, the model considers $\mathrm{C}$ losses from soil due to soil 
BM1
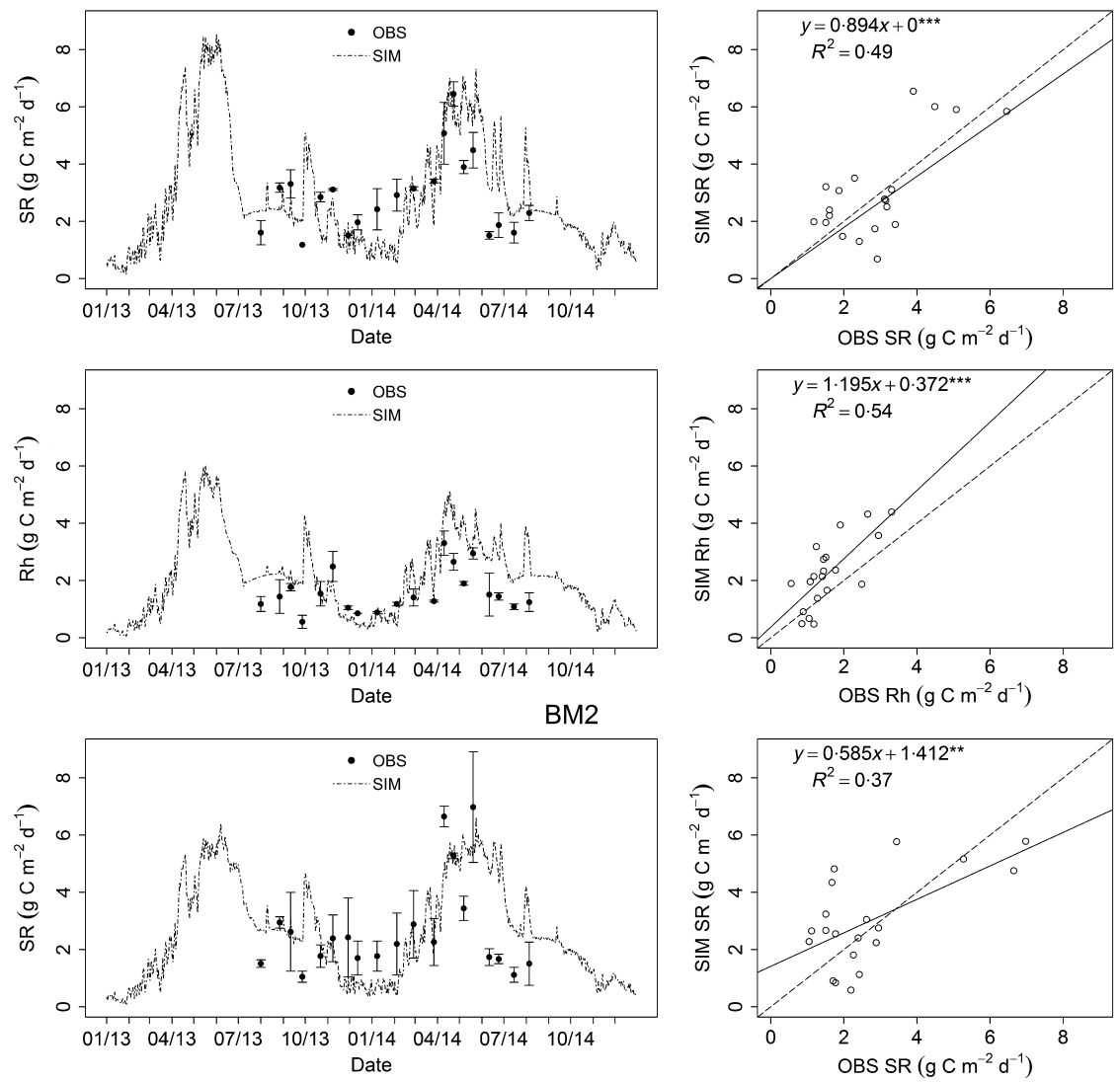

FIGURE 4 Calibration (BM1) and validation (BM2) results for SR (soil respiration, $\mathrm{g} \mathrm{C} \mathrm{m}^{-2} \mathrm{day}^{-1}$ ) and $\mathrm{Rh}$ (heterotrophic respiration, g C m ${ }^{-2}$ day $^{-1}$ ) and relation between observed (OBS) and simulated (SIM) data. Bars indicate the observed data standard error $(n=2)$. $(* * * p<.001 ; * * p<.01)$
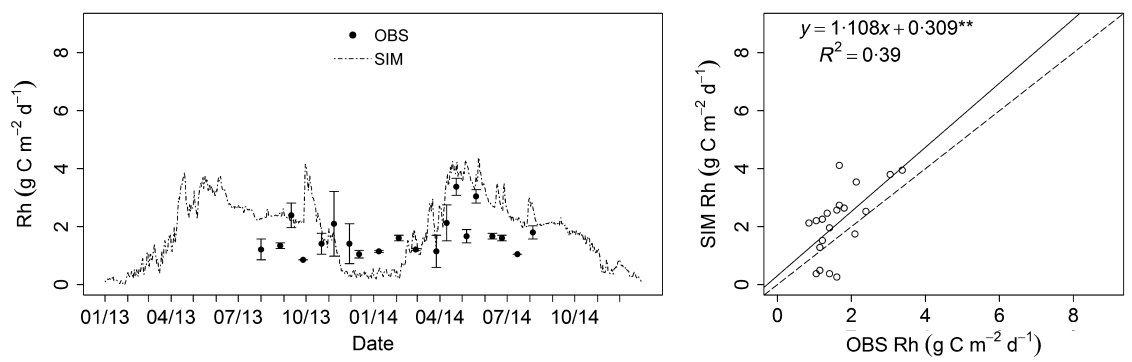

TABLE 4 Values of the metrics used to assess model performance in both calibration (Cal) and validation (Val) data sets

\begin{tabular}{|c|c|c|c|c|c|c|c|c|c|c|c|c|c|}
\hline \multirow[b]{2}{*}{ Observed Data } & \multirow[b]{2}{*}{ Years of available data } & \multicolumn{2}{|l|}{ BIAS } & \multicolumn{2}{|c|}{ RRMSE } & \multicolumn{2}{|l|}{ CRM } & \multicolumn{2}{|l|}{$\mathrm{EF}$} & \multicolumn{2}{|l|}{ d } & \multicolumn{2}{|l|}{$R^{2}$} \\
\hline & & Cal & Val & Cal & Val & Cal & Val & Cal & Val & Cal & Val & Cal & Val \\
\hline Soil T & 2014 & -0.834 & -1.275 & 18.44 & 19.68 & 0.05 & 0.07 & 0.73 & 0.74 & 0.94 & 0.94 & 0.84 & 0.80 \\
\hline NGDM & 2009-2010-2014 & 0.53 & -0.39 & 37.38 & 27.97 & -0.22 & 0.15 & 0.47 & 0.59 & 0.88 & 0.90 & 0.73 & 0.74 \\
\hline GRDM & 2009-2010-2013-2014 & 0.32 & 0.02 & 51.80 & 44.86 & -0.18 & -0.02 & 0.42 & 0.49 & 0.86 & 0.85 & 0.59 & 0.53 \\
\hline
\end{tabular}

GRDM = DM biomass in the grazed plots; NGDM = DM biomass in ungrazed plots; soil T = soil temperature; SWC, soil water content; SR, soil total respiration; Rh, soil heterotrophic respiration.

heterotrophic biota as the sum of $\mathrm{C}-\mathrm{CO}_{2}$ respiration from five $\mathrm{C}$ pools derived from the CENTURY model (Parton et al., 1993). The pools are characterized by different levels of $\mathrm{C}$ recalcitrance, with the addition of $\mathrm{C}-\mathrm{CO}_{2}$ losses from root exudates decomposition. The field Rh measurements performed in this study only allowed C-
$\mathrm{CO}_{2}$ fluxes to be observed due to the most recalcitrant soil $\mathrm{C}$. These differences, although quantitatively not important, might have generated a possible misalignment of observed and simulated data, thus adding further uncertainty to the prediction of the soil respiration processes. 

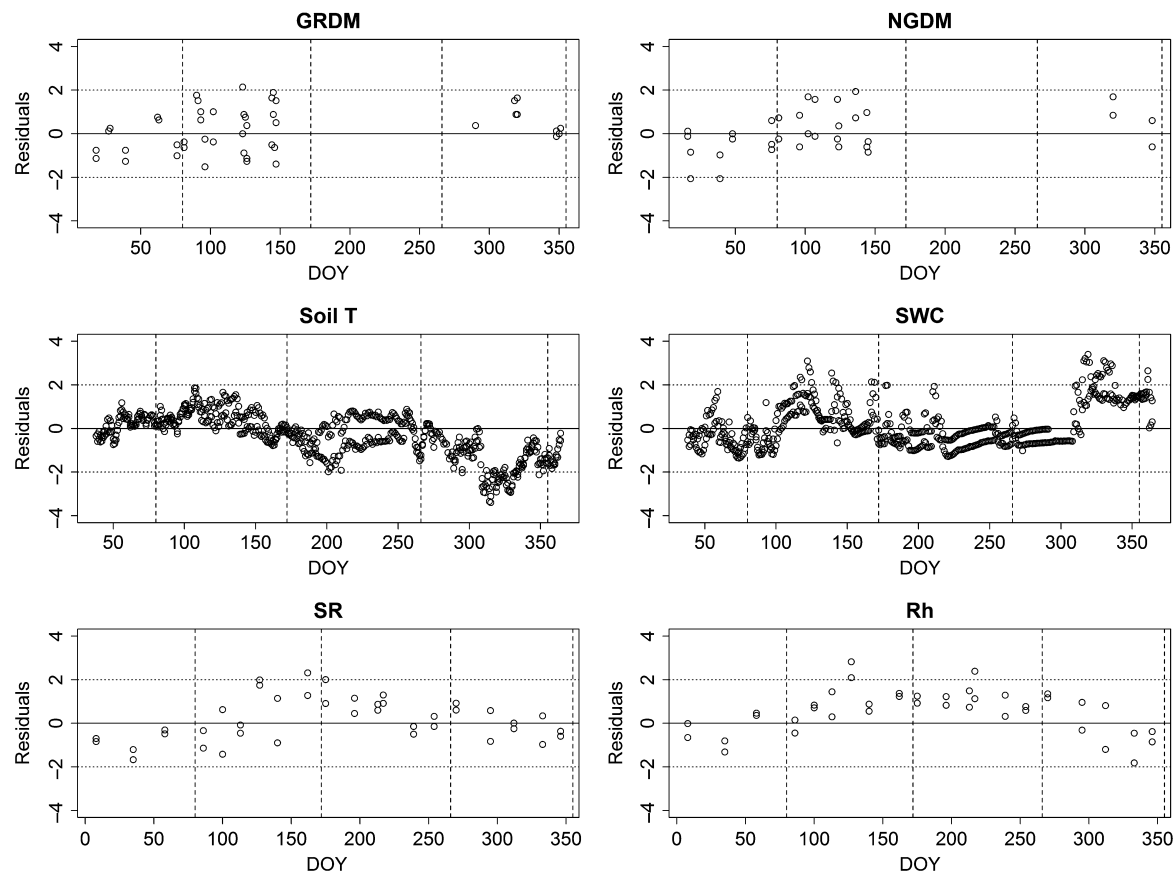

FIGURE 5 Standardized residuals analysis. Dashed vertical lines highlight seasons. Dashed horizontal lines indicate 95\% confidence bounds. GRDM = DM biomass in the grazed plots; NGDM = DM biomass in ungrazed plots; soil $\mathrm{T}=$ soil temperature; SWC, soil water content; $\mathrm{SR}=$ soil total respiration; $\mathrm{Rh}=$ soil heterotrophic respiration; DOY, day of year
The deviations of some PaSim parameters from published ranges or values, as obtained by calibration, reflect the profound differences between specific features of annual species that mostly comprise the Mediterranean grassland communities and perennial species typical of continental grassland swards. The parameter of relative root distribution was adjusted in order to feature the root allocation in a vegetation cover that consists mostly of annual species, these species having a shallower root system than perennial plants. Regarding light-saturated leaf photosynthetic rates, a lower calibrated value was obtained in the reproductive stage than the one suggested as minimum, while for the vegetative stage the calibrated value corresponded to the specified minimum limit. Considering that under conditions with $\mathrm{N}$ fertilization the calibrated parameters gave satisfactory estimates of biomass (see Supporting Information) such low values, yet outside the range of values previously set, likely reflect the biology of annual plants. It is known that grasses of the same genus may have different light-saturated photosynthesis rates in relation to their different biological cycles. As reported by Charles-Edwards, Charles-Edwards, and Sant (1974) in a multi-environment trial, the perennial species Lolium perenne L. showed higher rates of photosynthesis than the annual Lolium multiflorum Lam. With the obtained calibration, the shoot turnover parameter stretched to about 40 days, which is longer than the corresponding range of acceptable values (from about 18 to 27 days) for the conditions in which the model was developed. The life cycle of annual species is based on morphological and physiological features, which are expressed by the duration of the cycle and the allocation of assimilates, supporting the accumulation of resources for flowering and seed ripening (e.g., Schippers, Van Groenendael, Vleeshouwers, \& Hunt, 2001). The annual plants tend to invest mainly in seeds while abandoning the mother plant at an early stage (for annual selfreseeding). Alternatively, the perennial plants tend to invest mainly in long-lived and competitive adult individuals, while producing fewer seeds. Consequently, shoot turnover tends to be slower in annual plants than in perennial species, as the latter allocate more resources for the growth of new leaves, so as to maximize photosynthetic efficiency. Furthermore, in Mediterranean environmental conditions, if the dry season lasts too long (e.g., absence of precipitation in late summer and autumn), water deficits may negatively affect the capacity of plants for $C$ assimilation as a result of lower photosynthetic rates due to less developed leaf areas and shorter lifespan of the dominant annual plants with respect to perennials (Jongen, Pereira, Aires, \& Pio, 2011).

In conclusion, this work highlights the potential of PaSim to reasonably simulate grassland production dynamics and soil $\mathrm{CO}_{2}$ fluxes under Mediterranean conditions. In particular, the results suggest that PaSim could be a useful tool to simulate annual $C$ balances in Mediterranean grasslands. The limitations detected during the model assessment (e.g., shift of biomass production in autumn and summer Rh overestimation) indicate that PaSim requires further improvement to provide a better representation of the typical growth patterns of Mediterranean grassland ecosystems. Further model improvement could be targeted to represent better the peculiar dynamics of a grassland sward with a prevalence of annual species and the processes that control the turnover of organic matter and the associated Rh emissions during dry periods.

This study provides a basis for the development of scenario analyses and vulnerability assessment studies in relation to climate change, and to evaluate synergies and trade-offs between adaptation and mitigation strategies. This could also be achieved by exploiting the model capability to simulate annual biomass production under different management options such as livestock rates and animal types (cattle or sheep) and, in addition, under different cutting and fertilizer application regimes. 


\section{ACKNOWLEDGMENTS}

This study was carried out within three international research projects named "FACCE MACSUR-Modelling European Agriculture with Climate Change for Food Security, a FACCE JPI knowledge hub", "CN-MIP — C and N Models Intercomparison and Improvement to assess management options for GHG mitigation in agrosystems worldwide" and "MAGGNET_Quantifying Greenhouse Gas Mitigation Effectiveness through the GRA Croplands Greenhouse Gas Network" and in the context of the Italian PASCUUM research project (L.R. 7/2007, Sardinia Region). The research was carried out as part of $\mathrm{PhD}$ course on "Agricultural Science, Crop Productivity curriculum", carried out at the Department of Agriculture of the University of Sassari, Italy. The authors are very grateful to Mr. Agostino Piredda and Mr. Tore Pala from University of Sassari, and Mr. Gianfranco Becugna from AGRIS-Sardegna, Sassari, Italy, for their relevant contribution in the field experimental trials, from which it was possible to build the data set used this study. They are also grateful to Dr. Raphaël Martin from UREP-INRA, Clermont-Ferrand, France, for his technical support in the early stages of PaSim application. Furthermore, the authors are grateful to farms' owners who have hosted field experiments, Mr. Sebastiano Mu and Mr. Giovanni Casu.

\section{REFERENCES}

Addiscott, T., \& Whitmore, A. (1987). Computer simulation of changes in soil mineral nitrogen and crop nitrogen during autumn, winter and spring. The Journal of Agricultural Science, 109(01), 141-157.

Almagro, M., López, J., Querejeta, J., \& Martínez-Mena, M. (2009). Temperature dependence of soil $\mathrm{CO}_{2}$ efflux is strongly modulated by seasonal patterns of moisture availability in a Mediterranean ecosystem. Soil Biology and Biochemistry, 41(3), 594-605.

Bagella, S., Caria, M., Farris, E., Rossetti, I., \& Filigheddu, R. (2016). Traditional land uses enhanced plant biodiversity in a Mediterranean agrosilvo-pastoral system. Plant Biosystems-An International Journal Dealing with all Aspects of Plant Biology, 150(2), 201-207.

Bagella, S., Satta, A., Floris, I., Caria, M. C., Rossetti, I., \& Podani, J. (2013). Effects of plant community composition and flowering phenology on honeybee foraging in Mediterranean sylvo-pastoral systems. Applied Vegetation Science, 16(4), 689-697.

Bellocchi, G., Rivington, M., Donatelli, M., \& Matthews, K. (2010). Validation of biophysical models: Issues and methodologies. A review. Agronomy for Sustainable Development, 30(1), 109-130.

Ben Touhami, H., Lardy, R., Barra, V., \& Bellocchi, G. (2013). Screening parameters in the Pasture Simulation model using the Morris method. Ecological Modelling, 266, 42-57. https://doi.org/10.1016/j.ecolmodel. 2013.07.005

Caballero, R., Fernandez-Gonzalez, F., Badia, R. P., Molle, G., Roggero, P. P., Bagella, S., \& Ispikoudis, I. (2009). Grazing systems and biodiversity in Mediterranean areas: Spain, Italy and Greece. Pastos, 39(1), 9-152.

Cambardella, C., Moorman, T., Parkin, T., Karlen, D., Novak, J., Turco, R., \& Konopka, A. (1994). Field-scale variability of soil properties in central lowa soils. Soil Science Society of America Journal, 58(5), 1501-1511.

Carmignani, L., Oggiano, G., Funedda, A., Conti, P., Pasci, S., \& Barca, S. (Cartographer). (2012). Carta Geologica della Sardegna. Scala. 1:250.000

Cavallero, A., Talamucci, P., Grignani, C., Reyneri, A., Ziliotto, U., Scotton, M., \& Acutis, M. (1992). Caratterizzazione della dinamica produttiva di pascoli naturali italiani. Rivista Di Agronomia, 26(3 suppl.), 325-343.
Charles-Edwards, D. A., Charles-Edwards, J., \& Sant, F. I. (1974). Leaf photosynthetic activity in six temperate grass varieties grown in contrasting light and temperature environments. Journal of Experimental Botany, 25(87), 715-724.

Chen, S., Huang, Y., Zou, J., Shen, Q., Hu, Z., Qin, Y., \& Pan, G. (2010). Modeling interannual variability of global soil respiration from climate and soil properties. Agricultural and Forest Meteorology, 150(4), 590 605. https://doi.org/10.1016/j.agrformet.2010.02.004

Ciais, P., Soussana, J. F., Vuichard, N., Luyssaert, S., Don, A., Janssens, I. A., \& Schulze, E. D. (2010). The greenhouse gas balance of European grasslands. Biogeosciences Discussions, 7(4), 5997-6050. https://doi. org/10.5194/bgd-7-5997-2010

Correia, A. C., Minunno, F., Caldeira, M. C., Banza, J., Mateus, J., Carneiro, M., \& Pereira, J. S. (2012). Soil water availability strongly modulates soil CO2 efflux in different Mediterranean ecosystems: Model calibration using the Bayesian approach. Agriculture, Ecosystems \& Environment, 161, 88-100. https://doi.org/10.1016/j.agee.2012.07.025

Cosentino, S. L., Porqueddu, C., Copani, V., Patanè, C., Testa, G., Scordia, D., \& Melis, R. (2014). European grasslands overview: Mediterranean region. In A. Hopkins, R. P. Collins, M. D. Fraser, V. R. King, D. C. Lloyd, J. M. Moorby \& P. R. H. Robson (Eds.), Grassland Science in Europe, Vol. 19 - EGF at 50: The future of European grasslands(Vol. 50, pp. 4156). Proceedings of the 25th General Meeting of the European Grassland Federation: Aberystwyth, Wales (UK), 7-11 September 2014.

Costa, D., Freitas, H., \& Sousa, J. P. (2013). Influence of seasons and landuse practices on soil microbial activity and metabolic diversity in the "Montado ecosystem". European Journal of Soil Biology, 59, 22-30.

de Dato, G. D., De Angelis, P., Sirca, C., \& Beier, C. (2010). Impact of drought and increasing temperatures on soil $\mathrm{CO} 2$ emissions in a Mediterranean shrubland (gariga). Plant and Soil, 327(1-2), 153-166. https://doi.org/10.1007/s11104-009-0041-y

Davidson, E., Belk, E., \& Boone, R. D. (1998). Soil water content and temperature as independent or confounded factors controlling soil respiration in a temperate mixed hardwood forest. Global Change Biology, 4(2), 217-227

Davidson, E. A., \& Janssens, I. A. (2006). Temperature sensitivity of soil carbon decomposition and feedbacks to climate change. Nature, 440 (7081), 165-173.

EIP-AGRI. (2016). Profitability of permanent grasslands. Final Report. Retrieved from https://ec.europa.eu/eip/agriculture/sites/agri-eip/file s/eipagri_fg_permanent_grassland_final_report_2016_en.pdf

Fox, D. G. (1981). Judging air quality model performance. Bulletin of the American Meteorological Society, 62(5), 599-609.

Frame, J. (1981). Herbage mass. In J. Hodgson, R. Baker, A. Davies, \& A. Laidlaw (Eds.), Sward measurement handbook (pp. 39-67). Hurley, UK: The British Grassland Society.

Gea-Izquierdo, G., Montero, G., \& Cañellas, I. (2009). Changes in limiting resources determine spatio-temporal variability in tree-grass interactions. Agroforestry Systems, 76(2), 375-387. https://doi.org/10.1007/ s10457-009-9211-4

Golodets, C., Sternberg, M., Kigel, J., Boeken, B., Henkin, Z., Seligman, N. G., \& Ungar, E. D. (2015). Climate change scenarios of herbaceous production along an aridity gradient: Vulnerability increases with aridity. Oecologia, 177(4), 971-979. https://doi.org/10.1007/s00442-015-3234-5

Graux, A.-I., Bellocchi, G., Lardy, R., \& Soussana, J.-F. (2013). Ensemble modelling of climate change risks and opportunities for managed grasslands in France. Agricultural and Forest Meteorology, 170, 114 131. https://doi.org/10.1016/j.agrformet.2012.06.010

Graux, A. I., Gaurut, M., Agabriel, J., Baumont, R., Delagarde, R., Delaby, L., \& Soussana, J. F. (2011). Development of the Pasture Simulation Model for assessing livestock production under climate change. Agriculture, Ecosystems \& Environment, 144(1), 69-91. https://doi.org/10. 1016/j.agee.2011.07.001

Graux, A.-I., Lardy, R., Bellocchi, G., \& Soussana, J.-F. (2012). Global warming potential of French grassland-based dairy livestock systems 
under climate change. Regional Environmental Change, 12(4), 751-763. https://doi.org/10.1007/s10113-012-0289-2

Greenwood, D. J., Neeteson, J. J., \& Draycott, A. (1985). Response of potatoes to $\mathrm{N}$ fertilizer: Dynamic model. Plant and Soil, 85(2), 185203. https://doi.org/10.1007/bf02139623

Hanson, P., Edwards, N., Garten, C., \& Andrews, J. (2000). Separating root and soil microbial contributions to soil respiration: A review of methods and observations. Biogeochemistry, 48(1), 115-146.

Jongen, M., Pereira, J. S., Aires, L. M. I., \& Pio, C. A. (2011). The effects of drought and timing of precipitation on the inter-annual variation in ecosystem-atmosphere exchange in a Mediterranean grassland. Agricultural and Forest Meteorology, 151(5), 595-606. https://doi.org/10. 1016/j.agrformet.2011.01.008

Lai, R. (2011). Dinamica Spazio-temporale della Respirazione Eterotrofa del Suolo in un Sistema Agrario Mediterraneo. (PhD), Sassari, Sassari (IT).

Lai, R., Lagomarsino, A., Ledda, L., \& Roggero, P. P. (2014). Variation in soil $C$ and microbial functions across tree canopy projection and open grassland microenvironments. Turkish Journal of Agriculture and Forestry, 38(1), 62-69.

Lai, R., Seddaiu, G., Gennaro, L., \& Roggero, P. P. (2012). Effects of nitrogen fertilizer sources and temperature on soil $\mathrm{CO}_{2}$ efflux in Italian ryegrass crop under Mediterranean conditions. Italian Journal of Agronomy, 7(2), e27.

Lal, R. (2004). Soil carbon sequestration to mitigate climate change. Geoderma, 123(1-2), 1-22. https://doi.org/10.1016/j.geoderma.2004.01.032

Lardy, R., Bachelet, B., Bellocchi, G., \& Hill, D. R. C. (2014). Towards vulnerability minimization of grassland soil organic matter using metamodels. Environmental Modelling \& Software, 52, 38-50. https://doi. org/10.1016/j.envsoft.2013.10.015

Li, Y., Huang, M., Hua, J., Zhang, Z., Ni, L., Li, P., \& Zhu, L. (2015). Field observations of soil water content and nitrogen distribution on two hillslopes of different shape. Journal of Hydrology, 525, 694-705. https://doi.org/10.1016/j.jhydrol.2015.04.028

Loague, K., \& Green, R. E. (1991). Statistical and graphical methods for evaluating solute transport models: Overview and application. Journal of Contaminant Hydrology, 7(1), 51-73.

Ma, S., Lardy, R., Graux, A.-I., Ben Touhami, H., Klumpp, K., Martin, R., \& Bellocchi, G. (2015). Regional-scale analysis of carbon and water cycles on managed grassland systems. Environmental Modelling \& Software, 72, 356-371. https://doi.org/10.1016/j.envsoft.2015.03.007

Mekonnen, Z. A., Grant, R. F., \& Schwalm, C. (2016). Sensitivity of modeled NEP to climate forcing and soil at site and regional scales: Implications for upscaling ecosystem models. Ecological Modelling, 320, 241-257. https://doi.org/10.1016/j.ecolmodel.2015.10.004

Molle, G., Decandia, M., Cabiddu, A., Landau, S. Y., \& Cannas, A. (2008). An update on the nutrition of dairy sheep grazing Mediterranean pastures. Small Ruminant Research, 77(2), 93-112.

Oyonarte, C., Rey, A., Raimundo, J., Miralles, I., \& Escribano, P. (2012). The use of soil respiration as an ecological indicator in arid ecosystems of the SE of Spain: Spatial variability and controlling factors. Ecological Indicators, 14(1), 40-49.

Parton, W., Scurlock, J., Ojima, D., Gilmanov, T., Scholes, R., Schimel, D. S., \& Garcia Moya, E. (1993). Observations and modeling of biomass and soil organic matter dynamics for the grassland biome worldwide. Global Biogeochemical Cycles, 7(4), 785-809.

Porqueddu, C., Ates, S., Louhaichi, M., Kyriazopoulos, A. P., Moreno, G., del Pozo, A., \& Nichols, P. G. H. (2016). Grasslands in 'Old World' and 'New World' Mediterranean-climate zones: Past trends, current status and future research priorities. Grass and Forage Science, 71(1), 1-35. https://doi.org/10.1111/gfs.12212

Ravenna, M. (2013). II $6^{\circ}$ Censimento Generale dell'Agricoltura. In R. A. d. Sardegna (Ed.), II $6^{\circ}$ Censimento Generale dell'Agricoltura in Sardegna. Caratteristiche strutturali delle aziende agricole regionali (pp. 11-16). Cagliari, IT: Arti Grafiche Pisano.
RCoreTeam. (2014). R: A language and environment for statistical computing. Retrieved from https://cran.r-project.org/doc/manuals/fullrefman.pdf

Reichstein, M., Tenhunen, J., Roupsard, O., Ourcival, J. M., Rambal, S., Dore, S., \& Valentini, R. (2002). Ecosystem respiration in two Mediterranean evergreen Holm Oak forests: Drought effects and decomposition dynamics. Functional Ecology, 16(1), 27-39.

Rey, A., Pegoraro, E., Tedeschi, V., De Parri, I., Jarvis, P. G., \& Valentini, R. (2002). Annual variation in soil respiration and its components in a coppice oak forest in Central Italy. Global Change Biology, 8(9), 851866.

Riedo, M., Grub, A., Rosset, M., \& Fuhrer, J. (1998). A pasture simulation model for dry matter production, and fluxes of carbon, nitrogen, water and energy. Ecological Modelling, 105(2), 141-183.

Roggero, P. P., \& Porqueddu, C. (1999). The agronomic purpose of evaluation: Relating nurseries to field situations. In S. J. Bennett, \& P. S. Cocks (Eds.), Genetic resources of Mediterranean Pasture and Forage Legumes (pp. 107-119). Dordrecht: Springer, Netherlands.

Sándor, R., Barcza, Z., Hidy, D., Lellei-Kovács, E., Ma, S., \& Bellocchi, G. (2016). Modelling of grassland fluxes in Europe: Evaluation of two biogeochemical models. Agriculture, Ecosystems \& Environment, 215, 1-19. https://doi.org/10.1016/j.agee.2015.09.001

Saxton, K., \& Rawls, W. (2006). Soil water characteristic estimates by texture and organic matter for hydrologic solutions. Soil Science Society of America Journal, 70(5), 1569-1578.

Schippers, P., Van Groenendael, J. M., Vleeshouwers, L. M., \& Hunt, R. (2001). Herbaceous plant strategies in disturbed habitats. Oikos, 95 (2), 198-210.

Seddaiu, G., Porcu, G., Ledda, L., Roggero, P. P., Agnelli, A., \& Corti, G. (2013). Soil organic matter content and composition as influenced by soil management in a semi-arid Mediterranean agro-silvo-pastoral system. Agriculture, Ecosystems \& Environment, 167, 1-11.

Unger, S., Máguas, C., Pereira, J. S., Aires, L. M., David, T. S., \& Werner, C. (2009). Partitioning carbon fluxes in a Mediterranean oak forest to disentangle changes in ecosystem sink strength during drought. Agricultural and Forest Meteorology, 149(6), 949-961.

USDA. (2010). Keys to soil taxonomy (11th Edn). Washington, DC, USA: Soil Survey Staff, United States Department of Agriculture, Natural Resources Conservation Service.

Van Soest, P. J. (1994). Nutritional ecology of the ruminant. Ithaca, NY, USA: Cornell University Press.

Vital, J.-A., Gaurut, M., Lardy, R., Viovy, N., Soussana, J.-F., Bellocchi, G., \& Martin, R. (2013). High-performance computing for climate change impact studies with the Pasture Simulation model. Computers and Electronics in Agriculture, 98, 131-135.

Willmott, C. J., \& Wicks, D. E. (1980). An empirical method for the spatial interpolation of monthly precipitation within California. Physical Geography, 1(1), 59-73.

\section{SUPPORTING INFORMATION}

Additional Supporting Information may be found online in the supporting information tab for this article.

How to cite this article: Pulina A, Lai R, Salis L, Seddaiu G, Roggero PP, Bellocchi G. Modelling pasture production and soil temperature, water and carbon fluxes in Mediterranean grassland systems with the Pasture Simulation model. Grass Forage Sci. 2017;00:1-12. https://doi.org/10.1111/gfs.12310 